\title{
FOOD HABITS AND DIEL FEEDING RHYTHM OF INTRODUCED FISH, T. ZILLII GERVAIS, 1948 (PISCES: CICHLIDAE) IN LAKE ZWAI, ETHIOPIA
}

\author{
Alemayehu Negassa and Abebe Getahun* \\ Department of Biology, Faculty of Science, Addis Ababa University, PO Box 1176 \\ Addis Ababa, Ethiopia. E-mail: abebeg@bio.aau.edu.et
}

\begin{abstract}
Food habits of adult Tilapia zillii was studied in Lake Zwai from samples collected over 12 months during the year 2001 using gillnets of 60 and $100 \mathrm{~mm}$ stretched mesh. Younger fish caught in October, November and December using beach seine of $5 \mathrm{~mm}$ stretched mesh were also studied for food composition. Feeding rhythm of the fish was assessed based on samples collected in October 2001 over 24-hour period at 4-hour interval. Food items identified from stomach contents were analysed using the frequency of occurrence and the points methods. Macrophytes, detritus, blue greens, diatoms, green algae, Ceratium, Euglena and Phacus constituted food of plant origin whereas chironomid larvae, Copepoda, Cladocera, Rotifera, Nematoda, fish eggs and fish scales constituted food of animal origin. Furthermore, animal foods such as Ephemeroptera and molluscs were noted in the diet of adult fish. In adult T. zillii, macrophytes occurred in all of the stomachs examined and composed $86 \%$ of the diet whereas $11 \%$ was contributed by phytoplankton. However, in young fish phytoplankton constituted the bulk of the diet $(63 \%)$ followed by plant detritus $(17 \%)$ and chironomid larvae $(12 \%)$. The feeding pattern of $T$. zillii showed both diel and nocturnal rhythm; however, feeding was more intense during daytime.
\end{abstract}

\section{Key words/phrases: Ethiopia, feeding rhythm, food habits, Lake Zwai, Tilapia zillii}

\section{INTRODUCTION}

As elsewhere, a number of attempts have been made to introduce exotic freshwater fish species into Ethiopia with different intentions. Tilapia zillii is one of such species, and have been particularly introduced into several water bodies including Lake Zwai (Shibru Tedla and Fisseha H. Meskel, 1981). The fish was imported from Uganda by the Ministry of Agriculture and introduced to Lake Zwai in 1975 where it has successfully established itself and become an important component of the commercial catch.

T. zillii, an ecologically tolerant species, is widely distributed extending from West Africa through Chad basin to the Nile, Lake Albert and Lake Turkana into Israel and to Jordan valley (Trewavas, 1982). Moreover, the fish is of a first choice for introduction around the world because of its herbivorous habit and consequent weed control capabilities in irrigation channels and dams. It is essentially a macrophyte-feeder in which the adults feed preferentially on aquatic macrophytes and vegetable matter of terrestrial origin (Buddington, 1979; Philippart and Ruwet, 1982). In addition, the fish is known to feed on green and blue green algae and diatoms (Abdel Malek, 1972; Spataru, 1978; Khallaf and Alne-na-ei, 1987). It also takes animal food comprising benthic invertebrates (Abdel Malek, 1972), and insect larvae and crustacea (Khallaf and Alne-na-ei, 1987). Nevertheless, information concerning the feeding rhythm of $T$. zillii is extremely scanty despite the general variation in the feeding behaviour of tilapias according to the time of the day. Nothing is known about the biology of the species in Lake Zwai and elsewhere in Ethiopia (Abebe Getahun and Stiassny, 1998). Information on biology of the species is certainly vital for proper exploitation of the species, to make management decisions and for future development of culture fisheries in the country. Thus, the objective of this investigation was to determine the food habits and feeding rhythm of T. zillii in Lake Zwai.

Lake Zwai is located at $7052^{\prime}$ to $8^{0} 8^{\prime} \mathrm{N}$ latitude and $38^{\circ} 40^{\prime}$ to $38^{\circ} 56^{\prime} \mathrm{E}$ longitude, and lies at an altitude of $1636 \mathrm{~m}$ (Makin et al., 1975). The

\footnotetext{
* Author to whom correspondence should be addressed.
} 
sampling sites (Fig. 1) were located in the littoral zone at the south-western end of the lake and characterised by extensive macrophyte vegetation and sandy substratum. The littoral zone of the lake is fringed by emergent and submergent vegetation. The most common emergent plants are Scripus spp., Cyperus spp., Typha angustifolia, Paspalidium geminatum, and Phragmites sp. whereas the floating and submerged vegetation is represented by Nymphea coerulea and Potamogeton spp. (Tudorancea et al., 1999).

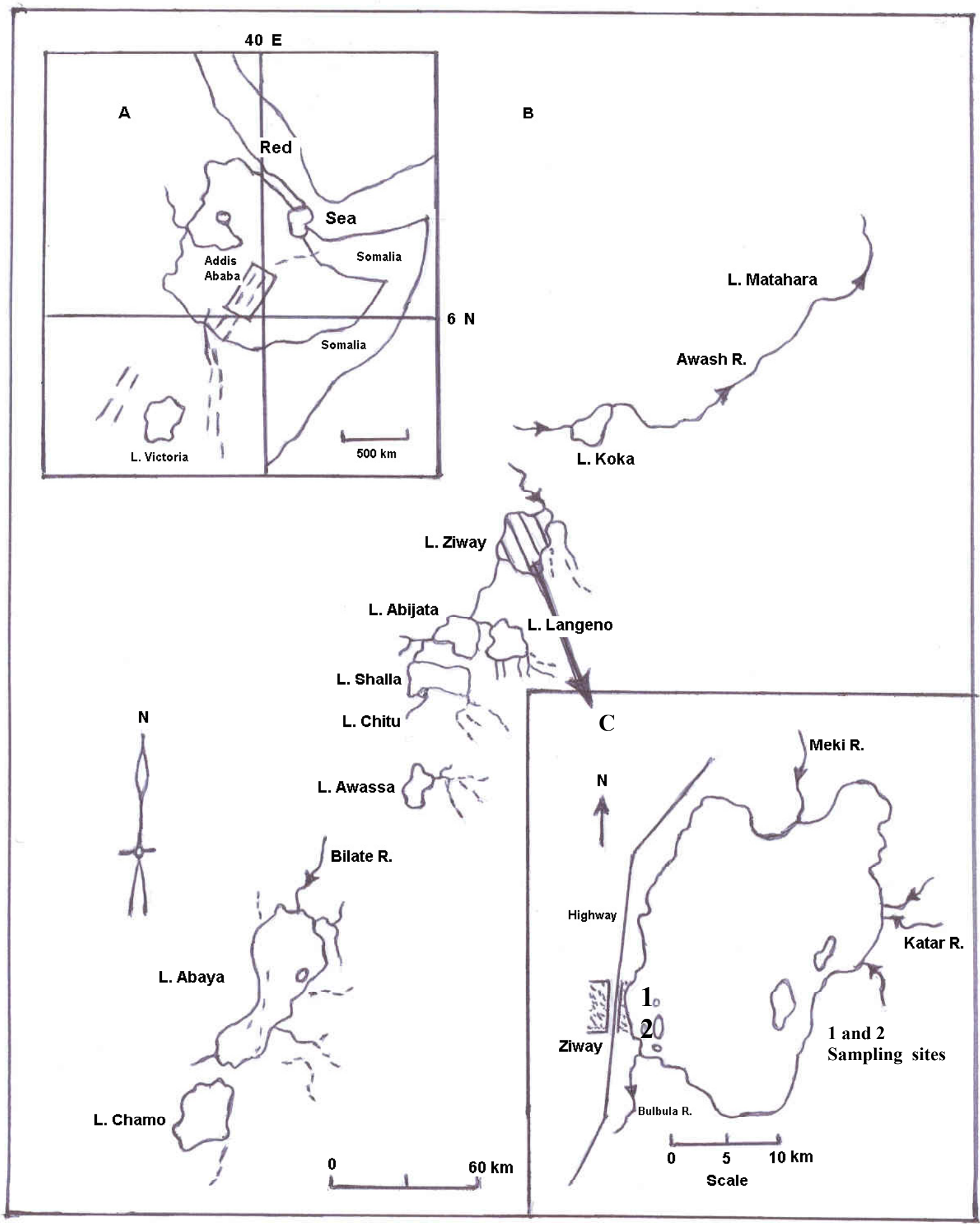

Fig. 1. Map of A) Ethiopia, B) Rift Valley lakes and C) Lake Zwai with the sampling sites. 
The phytoplankton community is dominated by blue green algae, of which Lyngbia limnetica, Microsystis aeruginosa and Synechococcus elongatus are the major species in terms of biomass. The diatoms, Melosira granulata, Navicula spp. and Surirella spp. and the green algae, Staurastrum leptocladum and Pediastrum boryannum are also important (Tsegaye Miheret-Ab, 1988).

Zooplankton community of the lake is composed of Cyclopoids (Mesocyclops spp., Microcyclops spp. and Afrocyclops spp.), Cladoceran (Diaphanosoma excisum and Alona davidii species) (Semeneh Belay, 1988), and Rotifers (Keratella species, Brachionus spp., Filinia spp., Hexarthra spp., Lecane spp., and Trichocerca spp.) (Green and Seyoum Mengistou, 1991). The bottom fauna comprises gastropod and chironomid larvae.

The fish community is composed of both native and introduced species. The native species comprise O. niloticus and some Barbus species whereas the introduced ones are T. zillii, Clarias gariepinus and Carassius auratus. The potential yield of all species combined is estimated in the range of 1000 to 6000 tones per year (LFDP, 1998).

\section{MATERIALS AND METHODS}

\section{Food habits}

Adult fish samples of T. zillii were collected over a twelve months period during the year 2001 using gill nets (60 and $100 \mathrm{~mm}$ stretched mesh) from the two sampling sites. In addition, younger fish were collected in October, November and December 2001, in shallow water less than $1 \mathrm{~m}$ depth, using a $5 \mathrm{~mm}$ stretched mesh beach seine. The sampling time for younger fishes is restricted to the rainy season because of logistic problems. Fish caught were taken to the Zwai Fisheries Resources Development Research Center laboratory soon after capture. In the laboratory, total length (TL) of all specimens was measured to the nearest $0.1 \mathrm{~cm}$ using a measuring board. The stomach of each fish was then removed and preserved in a plastic bag containing $5 \%$ formalin for later examination in the laboratory. Stomach samples were then transported to Addis Ababa University for further laboratory studies.

A study on the natural food of T. zillii was made based on stomach of 703 adults (12.5-32 cm TL) and 150 younger fish (5.5-12 cm TL). The categorisation of fish into two-length groups is based on changes in the major component of the diet. The stomach contents preserved in 5\% formalin were examined either with the naked eye or microscopically at several levels of magnifications. The food items were identified to the lowest taxonomic level possible using descriptions, illustrations and keys from various sources (Prescott, 1970; Whiteford and Schumacher, 1973; Harding and Smith, 1974; Pennak, 1978; Defaye, 1988). The frequency of occurrence and the points methods were used to describe the diet of the fish and to determine the relative importance of the different food items, respectively.

\section{Frequency of occurrence method}

The number of stomach samples in which one or more of a given food item was found was expressed as a proportion of all non-empty stomachs examined. This was considered as the proportion of the population that feeds on that particular food item and is referred to as frequency of occurrence (Hyslop, 1980).

\section{Points method}

The relative importance of the major food groups was estimated using points method which takes into account the abundance and volume of the food items (Windell and Bowen, 1978). The points method developed by Hynes (1950) was used as modified by Frost (1977). Accordingly, the stomach was opened and described based on the amount of food it contained, as full, $3 / 4$ full, $1 / 2$ full, quarter full, or trace and according to the degree of fullness was allotted 100,75,50, 25, 12, or 6 points, respectively. Stomach contents were then put on petridish and food items were sorted into macrophytes, phytoplankton and animal components. Each category was given points equivalent to its estimated contribution to the stomach volume. The points were then divided by 100 and multiplied by fullness index. The method requires no special apparatus for measurement. Volumes of larger food items were estimated visually and that of smaller ones was estimated relating to simple geometric figures after counting.

\section{Diurnal feeding rhythm}

A total of 129 T. zillii individuals were caught in October 2001 over a 24-hour period using beach seine of $80 \mathrm{~mm}$ stretched mesh size. The number of fish caught at $6,10,14,18,22$ and 2 hours at intervals of four hours were 22, 30, 25, 23, 17, and 12, respectively. After each capture, fish were immediately taken to the temporary laboratory near the shore, and total length and total weight 
were measured to the nearest $0.1 \mathrm{~cm}$ and $0.1 \mathrm{~g}$ using a measuring board and a balance (EK-1200A), respectively. The stomach of each fish was then isolated and weighed to the nearest $0.1 \mathrm{~g}$. The $\mathrm{pH}$ of the stomach contents was measured using a $\mathrm{pH}$ meter with glass electrodes. The stomach was then washed of its contents and weighed. The difference in weight between the full and washed stomach gave the wet weight of stomach contents. Wet weight of stomach contents in percent of body weight was considered as stomach fullness. The number of empty stomachs was also recorded for each time interval.

\section{RESULTS}

\section{Food habits}

Of the total 703 adult fish examined for food composition study, 605 (86\%) had food in their stomach. Analysis of the stomach contents showed that the diet of adult T. zillii in Lake Zwai was composed of diverse sources comprising both plants and animals (Table 1). The plant food was made up of macrophytes (unidentified) and phytoplankton including Cyanophyta (blue green algae), Bacillarophyta (diatoms), Chlorophyta (green algae), Dinophyta and Euglenophyta. Each of the first three families contributed several genera, many of which in turn contributed different species whereas Dinophyta was represented only by Ceratium sp. and Euglenophyta by Phacus sp. and Euglena sp. Chironomid larvae, Copepoda (Mesocyclopes sp.), Cladocera (Alona sp. and Diaphanosoma sp.),
Rotifera (Brachionus sp., Keratella sp. and Lecane sp.), Ephemeroptera, molluscs, and eggs and scales of unidentified fish constituted food of animal origin. Moreover, plant detritus and unidentified broken animal body parts were other components of the diet.

However, these food items occurred in the diet of the fish with different average percentage frequency (Fig. 2). Of all elements of the diet of adult $T$. zillii, macrophytes were the most frequent and occurred in all of the stomachs examined. As a group, blue greens, diatoms, green algae and plant detritus were found in $64 \%, 54 \%, 38 \%$ and $10 \%$ of the stomachs, respectively. Among blue greens Microcsysts spp. and Lyngbya spp. were frequent and noted in $59 \%$ and $33 \%$ of the stomachs, respectively, whereas Navicula (48\%) and Cymbella $(15 \%)$ were the diatoms with high frequency of occurrence. Spirogyra and Staurastrum (green algae) were relatively the most frequent and each occurred in $16 \%$ of the stomachs examined. Among foods of animal origin, chironomid larvae were the most frequent $(10 \%)$ followed by fish scales $(5 \%)$ and the remaining components were less frequent.

Further analysis in terms of percentage composition by points (Fig. 2) showed that macrophytes contributed the highest proportion $(86 \%)$ of the total food ingested. The remaining plant food items together formed about $12 \%$ of the diet in which blue green algae and diatoms contributed about $7 \%$ and $3 \%$, respectively. Animal food as a whole contributed not more than $2 \%$, of which chironomid larvae were relatively more important.

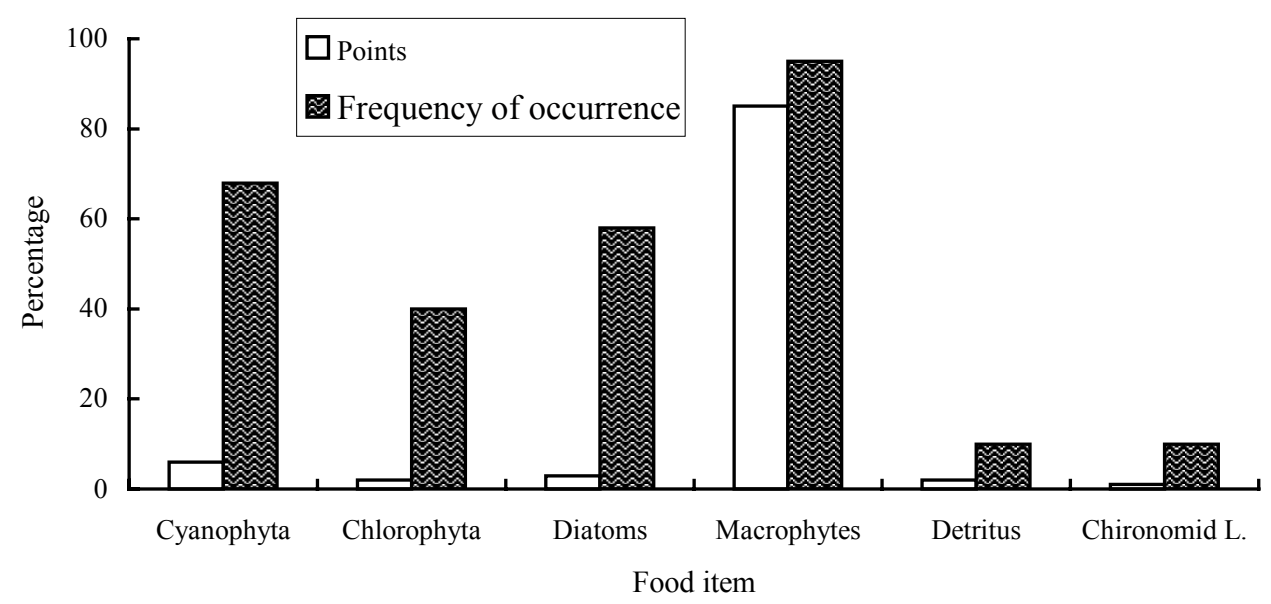

Fig. 2. Annual percentage frequency of occurrence (\% occur.) and composition of food (\% points) of adult T. zillii in Lake Zwai during the year 2001 . 
Table 1. Average percentage frequency of occurrence ( $\%$ occur.) of different food items identified in the stomachs of adult and young $T$. zillii collected from Lake Zwai during the year 2001.

\begin{tabular}{|c|c|c|}
\hline \multirow[b]{2}{*}{ Food category } & \multicolumn{2}{|c|}{ (\% occur.) (T. zillii) } \\
\hline & Adult & Young \\
\hline A. Macrophytes & 100 & 40 \\
\hline \multicolumn{3}{|l|}{ B. Phytoplankton } \\
\hline i. Cyanophyta & 64 & 86 \\
\hline Anabaena & 18 & 32 \\
\hline Chroococcus & 7 & 8 \\
\hline Gloeocapsa & 0.4 & 4 \\
\hline Lyngbya & 33 & 55 \\
\hline Merismopedia & 11 & 28 \\
\hline Microcsysts & 59 & 91 \\
\hline Oscillatoria & 33 & 54 \\
\hline Spirulina & 1 & 3 \\
\hline ii. Bacillarophyta & 54 & 96 \\
\hline Achnanthes & 0.4 & 25 \\
\hline Cyclotella & 11 & 30 \\
\hline Cymbella & 15 & 59 \\
\hline Denticula & -- & 5 \\
\hline Frustulia & -- & 7 \\
\hline Gomphonema & 0.2 & -- \\
\hline Navicula & 48 & 84 \\
\hline Nitzschia & 2 & 18 \\
\hline Opephora & 0.4 & -- \\
\hline Rhoicosphenia & 4 & 4 \\
\hline Rhopalodia & 10 & 78 \\
\hline Surirella & -- & 9 \\
\hline Synedra & 13 & -- \\
\hline iii. Chlorophyta & 38 & 59 \\
\hline Ankistrodesmus & 2 & -- \\
\hline Botryococcus & 2 & -- \\
\hline Coelastrum & 6 & 5 \\
\hline Closterium & 8 & 21 \\
\hline Cosmarium & 3 & 3 \\
\hline Euastrum & 2 & 1 \\
\hline Pediastrum & 4 & 2 \\
\hline Scendesmus & 6 & 32 \\
\hline Spirogyra & 16 & 10 \\
\hline Staurastrum & 16 & 10 \\
\hline Tetradron & 0.2 & -- \\
\hline C. Detritus & 10 & 83 \\
\hline D. Chironomid larvae & 10 & 58 \\
\hline \multicolumn{3}{|c|}{ E. Zooplankton } \\
\hline Copepoda & 1 & 3 \\
\hline Cladocera & 0.6 & -- \\
\hline Rotifera & 0.9 & -- \\
\hline \multicolumn{3}{|l|}{ F. Others } \\
\hline Ceratium & 8 & 4 \\
\hline Euglena & 1 & 0.3 \\
\hline Phacus & 0.2 & 0.2 \\
\hline Nematoda & 0.4 & -- \\
\hline Ephemeroptera & 0.4 & -- \\
\hline Molluscs & 0.4 & -- \\
\hline Fish egg & 0.6 & -- \\
\hline Fish scale & 5 & 13 \\
\hline Unidentified species & 0.8 & -- \\
\hline
\end{tabular}

All young T. zillii examined for diet had food in their stomachs, which was similar to that of the adults both in terms of composition and diversity (Table 1). In accordance, food of plant origin was composed of diatoms, blue green algae, green algae, plant detritus, macrophytes, Ceratium, Phacus and Euglena whereas chironomid larvae, Copepoda, Rotifera and fish scales formed food of animal origin.

These food items had different frequency of occurrence in the diet of the young fish (Fig. 3). As a group, diatoms, blue green algae and green algae occurred in $96 \%, 86 \%$ and $59 \%$ of the total stomach of young T. zillii examined, respectively. From diatoms, Navicula (84\%), Rhopalodia (78\%) and Cymbella (59\%); and from blue green algae Microcsysts (91\%), Lyngbya (55\%) and Oscillatoria (54\%) were the most frequent food items. Among green algae, Scenedesmus (32\%) and Closterium (21\%) were relatively frequent. Plant detritus were found in $83 \%$ and macrophyte in $40 \%$ of the stomachs. Of animal food components, chironomid larvae occurred in $58 \%$ of the stomachs examined and the rest were less frequent.

When rated in terms of percentage composition by points (Fig. 3), plant components formed $86 \%$ of the food of young T. zillii, of which about $63 \%$ was contributed by phytoplankton belonging to diatoms $(31 \%)$, blue green algae $(21 \%)$ and green algae $(11 \%)$. Plant detritus and macrophytes contributed $17 \%$ and $6 \%$, respectively. Among foods of animal origin chironomid larvae constituted $12 \%$, however, the contribution made by the rest (Copepoda and fish scales) was insignificant.

\section{Diurnal feeding rhythm}

The proportion of empty stomachs of T. zillii in Lake Zwai varied during the sampling periods of the day (Fig. 4). No empty stomach was recorded in samples taken between 6:00 and 14:00 h, but empty stomachs of lower proportion were observed between 14:00 $\mathrm{h}$ and 18:00 $\mathrm{h}$, and the highest proportion was recorded between 18:00 $\mathrm{h}$ and 2:00 h. Nevertheless, the proportion dropped from 2:00 to $6: 00 \mathrm{~h}$. This variation in the proportion of empty stomach recorded during each time of capture indicated the feeding pattern of T. zillii. Accordingly, the fish was found to be both daytime and nocturnal feeder. 


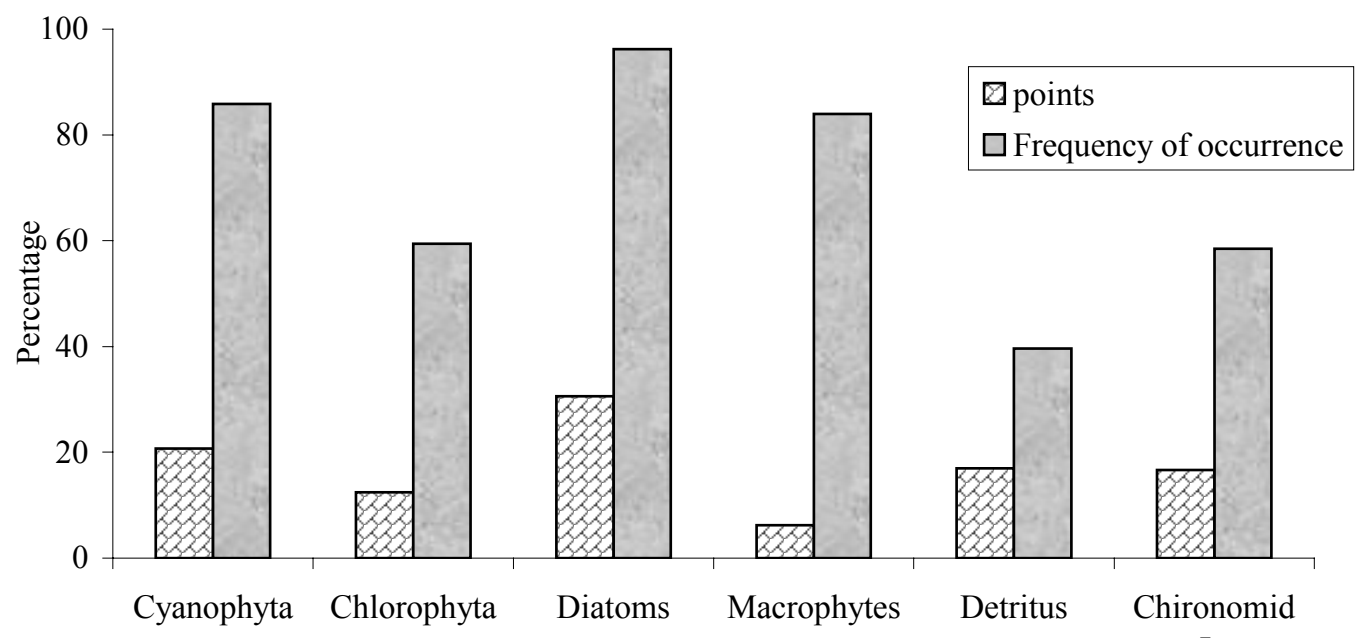

Food item

L.

Fig. 3. Annual percentage frequency of occurrence ( $\%$ occur.) and composition (\% points) of young T. zillii in Lake Zwai during the year 2001.

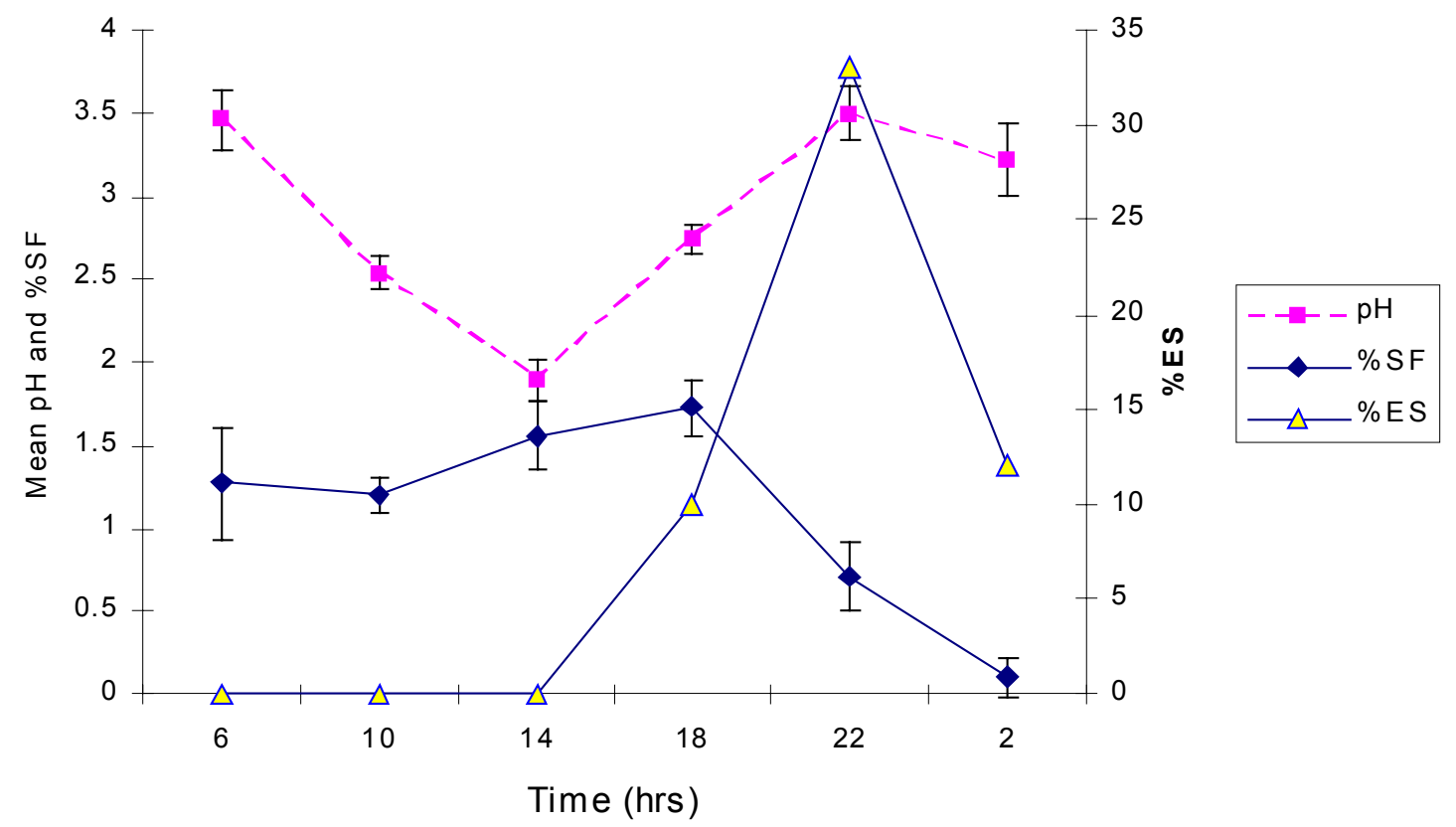

Fig.4. Diel changes in stomach pH (mean \pm SE), percentage of stomach fullness $(\% \mathrm{SF})$ (mean \pm SE) and percentage of empty stomachs (\%ES) of T.zillii in Lake Zwai.

The average percent stomach fullness (Fig. 4) remained high between 6:00 and 10:00 $\mathrm{h}$, and further increased to the highest point at 18:00 h. It then dropped to the lowest point at 2:00 h and increased between 2:00 and 6:00 h. Stomach $\mathrm{pH}$ (Fig. 4) of T. zillii in Lake Zwai decreased continuously starting from 6:00 h and reached a value as low as 1.89 at 14:00 $\mathrm{h}$ and then, increased progressively from $14: 00 \mathrm{~h}$ to $2: 00 \mathrm{~h}$. There was also an instant where a $\mathrm{pH}$ of 1.24 was measured at 14:00 h. 


\section{DISCUSSION}

The frequency of occurrence and the points methods were used to describe the diet of the fish and to determine the relative importance of the different food items, respectively. Though the former method may be employed in any diet study the method used in quantifying food items may vary with the nature of the diet. The diet of $T$. zillii is composed mainly of macrophytes, for which counting is not appropriate since the food items are fragmented and are not uniform size. Direct volumetric or gravimetric method could be applied if macrophytes are the sole food items. However, the fish also feeds on phytoplankton and animal components and this made the points method relatively more appropriate.

Stomach content analysis based on the occurrence method showed that in Lake Zwai both adult and young T. zillii had a broad natural food base comprising both plants and animals (Table 1). Nevertheless, food of plant origin was the major component of the diet. The same has been reported for adults from Lake Victoria by Welcomme (1967) and from Nile canal by Khallaf and Alne-na-ei (1987) and for fish belonging to both length groups from Lake Quarun by Abdel-Malek (1972).

Analysis using the frequency of occurrence and the points methods showed that the diet of $T$. zillii in Lake Zwai varied depending on the size of the fish (Figs. 3 and 4) as it chiefly feeds on macrophytes as adult and phytoplankton as young. In adults higher plant tissue including large portions of roots, leaves and stems of aquatic vegetation and seeds occurred in all of the stomachs examined and constituted $86 \%$ of the diet. Several authors (Welcomme, 1967; Abdel Malek, 1972; Balarin and Hatton, 1979; Buddington, 1979; Khallaf and Alne-na-ei, 1987) also reported that $T$. zillii feeds essentially on plant material and is consistent with the present observation. On the other hand, blue green algae, diatoms and green algae together composed about $11 \%$ of the diet. These items were also reported to be ingested by the fish from Lake Quarun (AbdelMalek, 1972), Lake Kinnert (Spataru, 1978) and Nile canal (Khallaf and Alne-na-ei, 1987). However, in young fish phytoplankton (blue green algae, diatoms and green algae) constituted the bulk of the diet (63\%) followed by plant detritus $(17 \%)$ and chironomid larvae $(12 \%)$ whereas macrophytes contributed not more than $6 \%$.

This diet variation with size of the fish may be due to differences in the degree of development of structures used for feeding and the habitat occupied by the fish. It could be that adults have well developed teeth to utilize macrophytes more efficiently than younger ones. Philippart and Ruwet (1982) also reported the variation in the feeding regime of fish species depending on size, age and the microhabitat occupied by the fish in a given water body.

The occurrence of planktonic material in the guts of fishes with no filter feeding mechanism as is the case in T. zillii is a strange phenomenon. However, Welcomme (1967) suggested the source of planktonic material in the diet of T. zillii in Lake Victoria to be flocculent deposits off shore. On the other hand, the occurrence of larger animals like molluscs in the diet of adult T. zillii but not in that of young ones may be attributed to prey-predator size relationship. Abdel-Malek (1972) also associated the change in composition of the diet, as the fish grows in size to an increase in the minimum size of the organism eaten.

The feeding of T. zillii in Lake Zwai appeared to have both diel and nocturnal rhythm; however, feeding was more intense during daytime with the highest of activity in the afternoon. Khallaf and Alne-na-ei (1987) also reported that feeding in the fish was correlated to water temperature not to daily photoperiod. In addition, Cridland (1962) from his laboratory experiment noted that water temperature, and not photoperiod, affected growth of T. zillii in tanks. Nevertheless, some fish had empty stomach even during the day and this could be attributed to disease, which might have restrained feeding in these fish. Getachew Teferra (1989) has drawn similar conclusion for O. niloticus with empty stomachs observed during daytime when the fish is assumed to feed.

There was some association between the amount of food ingested and the $\mathrm{pH}$ of the stomach (Fig. 4). The $\mathrm{pH}$ of the stomach was lower during the afternoon when stomach fullness was relatively higher. As reported for other species including $O$. niloticus (Getachew Teferra, 1989) food in the stomach acts as stimulant towards the secretion of acid and consequently decreases $\mathrm{pH}$ and the same may hold true in T. zillii as well. However, $\mathrm{pH}$ started increasing when fullness was at its greatest value at 18:00 $\mathrm{h}$ to its maximum value at 2:00 h. The increase in $\mathrm{pH}$ value while fullness was at its highest point might be due to higher proportion of small sized stomachs, which could affect the reading, as the electrode was not fully immersed in the stomach contents. The difference in number of fish sampled in each time interval may also be important. 
In conclusion, T. zillii grows to large size (up to $32 \mathrm{~cm}$ ) in Lake Zwai and appears good in utilizing aquatic macrophytes especially as adult perhaps as intended when introduced. The preferred habitat of the fish was the shallow marginal waters of the lake and hence it can be better harvested from such areas when breeding is not at its climax with gillnets set especially during day time as it intensively feeds during day time.

\section{ACKNOWLEDGEMENTS}

We would like to thank the Swedish Agency for Research and Education for Developing Countries (SAREC) and the Rockefeller Foundation (Grant No. 2001AR 002) for financial support and the meteorological data provided by the National Meteorology Services Agency. We also extend our sincere thanks to fishermen of Lake Zwai who helped us in sample collection of whom Gezahegn Tilinti and Mulatu Galato deserve especial consideration.

\section{REFERENCES}

1. Abdel-Malek, S.A. (1972). Food and feeding habits of some Egyptian fishes in Lake Quarun:Tilapia zillii (Gerv.) B. According to different length groups. Bulletin of the Institute of Oceanography and Fisheries, pp. 205-213.

2. Abebe Getahun and Stiassny, M.L.J. (1998). The freshwater biodiversity crisis:the case of the Ethiopian fish fauna. SINET: Ethiop. J. Sci. 21(2):207230.

3. Balarin, J.D. and Hatton, T.J. (1979). Tilapia: A guide to their biology and culture in Africa. University of Stirling, Scottland, pp. 1-42.

4. Buddington, R.K. (1979). Digestion of an aquatic macrophyte by T. zillii. J. Fish Biol. 15:449-456.

5. Cridland, C.C. (1962). Laboratory experiments on the growth of Tilapia species: the effect of light and temperature on the growth of $T$. zillii in aquaria. Hydrobiologia 20:155-167.

6. Defaye, D. (1988). Contribution a la connaissance des crustaces copepods d'Ethiopie. Hydrobiologia 164:103-147.

7. Frost, W.E. (1977). The food of Charr, Salvelinus willughbii (Gunther), in Windermere. J. Fish Biol. 11:531-547.

8. Getachew Teferra (1989). Stomach $\mathrm{pH}$, feeding rhythm and ingestion rate in Oreochromis niloticus L. (Pisces: Cichlidae) in Lake Awassa, Ethiopia. Hydrobiologia 174:43-48.

9. Green, J. and Seyoum Mengistou (1991). Specific diversity and community structure of Rotifera in a salinity series of Ethiopian inland waters. $\mathrm{Hy}$ drobiologia 209:95-106.

10. Harding, J.P. and Smith, W.A. (1974). A key to the British freshwater Cyclopoid and Calanoid Copepods. Freshwater Biological Association Scientific Publication No.18. Titus Wilson and Son Ltd. London, $54 \mathrm{pp}$.

11. Hynes, H.B.N. (1950). The food of freshwater Sticklebacks (Gasterosteus aculeatus and Pygosteus pungitius) with a review of methods used in studies of the food of fishes. J. Anim. Ecol. 19(1):36-58.

12. Hyslop, E.J. (1980). Stomach contents analysis-a review of methods and their application. J. Fish Biol.. 17:411-429.

13. Khallaf, E.A. and Alne-na-ei, A.A. (1987). Feeding ecology of Oreochromis niloticus (Linnaes) and Tilapia zillii (Gervais) in a Nile canal. Hydrobiologia 146:57-62.

14. LFDP (1998). Fisheries Report, phase II. Animal and Fisheries Resources Development Department (MOA). Addis Ababa, Ethiopia. 61 pp.

15. Makin, M., Kingham, J.J., Waddam, A.E., Birchal, C.J. and Tamene Tefera (1975). Development projects in the Southern Rift Valley of Ethiopia. Land Resources Study 21. Land Resources Division, Ministry of Overseas Development, England.

16. Pennak, R.W. (1978). Freshwater invertebrates of the United States. John Wiley and Sons, New York, $803 \mathrm{pp}$.

17. Philippart, J-CL. and Ruwet, J-CL. (1982). Ecology and distribution of tilapias. In: The Biology and Culture of Tilapias, pp. 15-59, (Pullin, R.S.V. and Lowe-McConnell, R.H., eds). Proceedings of the international conference, ICLARM, Manilla, Phillipines.

18. Prescott, G.W. (1970). How to Know the Fresh Water Algae. Brown, W.M.C., Dubuque, Iowa, 348 pp.

19. Semeneh Belay (1988). Zooplankton composition and seasonal dynamics in Lake Zwai, Ethiopia M.Sc. Thesis, School of Graduate Studies, Addis Ababa University, 121 pp.

20. Shibru Tedla and Fisseha H. Meskel (1981). Introduction and transplantation of freshwater fish species in Ethiopia. SINET: Ethiop. J. Sci. 4:69-72.

21. Spataru, P. (1978). Food and feeding habits of T. zillii (Gervais) (Cichlidae) in Lake Kinnert (Israel). Aquaculture 14:327-338.

22. Trewavas, E. (1982). Taxonomy and speciation. In: The Biology and Culture of Tilapias, pp. 3-13, (Pullin, R.S.V. and Lowe-McConnell, R.H., eds). Proceedings of the international conference, ICLARM,.Manila, Philippines.

23. Tsegaye Miheret-Ab (1988). A seasonal study of phytoplankton primary production in relation to light and nutrients in Lake Zwai, Ethiopia M.Sc. Thesis, School of Graduate Studies, Addis Ababa University, $72 \mathrm{pp}$.

24. Tudorancea, C., Zinabu G/Marium and Elias Dadebo (1999). Limnology in Ethiopia. In: Limnology in Developing Countries, Vol. 2, pp. 63-118, (Wetzel, R.G. and Gopal, B., ed.). International Association for Limnology.

25. Welcomme, R.L. (1967). Observations on the biology of the introduced species of tilapia in Lake Victoria. Rev. Zool. Bot. Afr. LXXVI, 3-4.

26. Whitford, L.A. and Schumacher, G.J. (1973). A Manual of Fresh Water Algae. Sparks Press, Raleigh, NC. $324 \mathrm{pp}$.

27. Windell, J.T. and Bowen, S.H. (1978). Methods for study of fish diets based on analysis of stomach contents. In: Methods for the Assessment of Fish Production in Fresh Waters, 3rd ed., pp. 219-226, (Bagnel, T., ed.) Blackwell Scientific Publications, Oxford. 